\title{
Impact of psychosocial stress on gonadotrophins and sexual behaviour in females: role for cortisol?
}

\author{
C R Ralph¹, M N Lehman², R L Goodman³ and A J Tilbrook ${ }^{1}$ \\ ${ }^{1}$ Division of Livestock and Farming Systems, South Australian Research and Development Institute, \\ The University of Adelaide, Adelaide, Australia, ${ }^{2}$ Department of Physiology and Biophysics, \\ University of Mississippi Medical Center, Jackson, Mississippi, USA, and ${ }^{3}$ Department of Physiology and \\ Pharmacology, West Virginia University, Morgantown, West Virginia, USA
}

Correspondence should be addressed to A J Tilbrook; Email: alan.tilbrook@sa.gov.au

\begin{abstract}
This review focuses on the importance of cortisol in mediating the inhibitory effects of psychosocial stress on reproduction in females. In particular, we have summarized our research in sheep where we have systematically established whether cortisol is both sufficient and necessary to suppress reproductive hormone secretion and inhibit sexual behaviour. Our findings are put into context with previous work and are used to develop important concepts as well as to identify productive further lines of investigation. It is clear that cortisol is necessary to inhibit some, but not all, aspects of reproduction in female sheep. These actions vary with reproductive state, and there are important interactions with gonadal steroids. The impact of cortisol on the tonic secretion of gonadotrophin-releasing hormone and luteinizing hormone has been investigated extensively, but less is known about the surge secretion of these hormones and their effects on sexual behaviour. Furthermore, there are separate effects of cortisol in the brain (hypothalamus) and at the anterior pituitary, illustrating that there are different mechanisms of action. Thus, although cortisol is important in mediating some of the effects of stress on reproduction, we need to look beyond cortisol and investigate some of the other mechanisms and mediators that relay the effects of stress on reproduction. In this regard, we propose that a group of neurons in the hypothalamus that co-synthesize kisspeptin, neurokinin B and dynorphin, termed KNDy cells, play important roles in mediating the effects of cortisol on reproduction. This hypothesis needs to be rigorously tested.

Reproduction (2016) 152 R1-R14
\end{abstract}

\section{Introduction}

Stress is commonly defined as a state of disrupted homeostasis or a threat to homeostasis caused by stimuli known as stressors. Stressors are many and varied and may include environmental extremes, trauma, immune and inflammatory reactions, altered metabolic demand and psychological challenges or pressures due to distressing events, or even simply coping with the trials of everyday life. Any of these stressors can affect reproduction in females by interfering with function at various levels including the brain, the anterior pituitary gland and the ovaries. The outcomes include inhibition of ovulation and sexual behaviour. The deleterious effects of stress on reproduction have far reaching implications for fertility in humans, production efficiency in livestock that provide food and fibre, and propagation of endangered species whose survival is threatened. The mechanisms and mediators by which stress leads to negative reproductive outcomes, however, are not well understood. Many mediators of the inhibitory effects of stress on reproduction have been proposed, including catecholamines, opioids, cytokines and hormones of the hypothalamicpituitary-adrenal (HPA) axis. As a hallmark of stress is activation of the HPA axis with increased synthesis of glucocorticoids, these steroids have been the subjects of extensive research to determine whether they inhibit reproductive function. In most mammalian species, the principal glucocorticoid synthesized when the HPA axis is activated is cortisol, whereas in rodents and avian species, it is corticosterone.

In addition to stress-induced increases in glucocorticoids, there are clinical conditions in humans, and some animals, in which the concentrations of cortisol are pathologically high, and this is associated with reproductive dysfunction. These conditions include Cushing's syndrome (Bertagna et al. 2009, Spencer \& Tilbrook 2011), Cushing's disease (Bertagna et al. 2009, Spencer \& Tilbrook 2011), obesity (Berga et al. 1997), metabolic syndrome (Berga et al. 1997), functional hypothalamic amenorrhoea (Sapolsky et al. 2000), hyperthyroidism (Breen \& Karsch 2004), diabetes mellitus type II (Berga et al. 1997), hypertension (Berga et al. 1997) and major depression (Berga et al. 1997). 
Thus, the need to understand how glucocorticoids affect reproduction extends beyond stressful events, although stress is pervasive in our society, farming systems, zoos and wildlife.

Although there has been a vast amount of research on the role of cortisol as a mediator of the effects of stress on reproduction, much of this has been inconclusive and controversial, and a systematic coordinated approach had not been performed in any species. To address this, we developed sheep models of psychosocial stress, which is a prevalent type of stress in today's society and in animal populations. We have (1) characterized the impact of this stress type on HPA activation, (2) dissected separate disruptive actions of this stress on reproductive neuroendocrine function at the hypothalamic and pituitary levels, and (3) determined whether such stress interferes with various reproductive behaviours in a way that decreases the likelihood that animals will mate. With these findings in hand, we next tested whether the rise in cortisol secretion induced by psychosocial stress mediates the negative reproductive outcomes. We utilized powerful in vivo models and a systematic and coordinated approach to determine whether cortisol is both necessary and sufficient to account for disruptive effects of psychosocial stress on secretory profiles of gonadotrophin-releasing hormone (GNRH), responsiveness of the anterior pituitary gland to GNRH and reproductive behaviours. Based on the results, we put forward the novel proposition that a group of neurons in the hypothalamus that co-synthesize the neuropeptides kisspeptin (KISS), neurokinin B (NKB) and dynorphin (DYN), and that has been termed "KNDy" cells, play important roles in centrally mediating the inhibitory effects of cortisol on reproduction.

This review highlights key aspects of our research with sheep and puts our findings into context with previous work in the field. In this review, we develop important concepts as well as identify productive further lines of investigation to address how stress limits reproduction.

\section{Neuroendocrine regulation of reproduction in females}

The endocrine regulation of reproduction in mammalian females has been extensively reviewed in and is well understood (Goodman 2014). We have studied sheep in which the neuroendocrine regulation of reproduction has been characterized in detail (Goodman 2014). Reproduction is controlled by the brain where GNRH, synthesized by neurons, is secreted from axon terminals in the median eminence of the hypothalamus directly into the pituitary portal system and is transported to the anterior pituitary gland. There it stimulates the synthesis and secretion of the gonadotrophins, luteinizing hormone ( $\mathrm{LH})$ and follicle-stimulating hormone (FSH). The pattern of secretion of GNRH is critical for function.
A pulsatile pattern ensures appropriate secretion of $\mathrm{LH}$ and FSH for ovarian function during most of the follicular and luteal phase (referred to as tonic secretion), and a surge in GNRH secretion at the end of the follicular phase ultimately induces ovulation. GNRH also stimulates some aspects of sexual behaviour. The pattern of secretion of $\mathrm{LH}$, in particular, is tightly coupled to that of GNRH, in both pulsatile and surge patterns. Normal ovarian function includes production of gametes and hormones, such as the steroids oestradiol and progesterone. The sex steroids are essential for normal reproductive function and act as feedback regulators of $\mathrm{GNRH}$ and gonadotrophin secretion and as stimulants or inhibitors of sexual behaviour.

Our strategy to investigate the impact of cortisol on secretion of GNRH and LH and behaviour has been to systematically establish whether cortisol is both sufficient and necessary to suppress reproductive hormone secretion and inhibit sexual behaviour. An essential element of this strategy has been the use of an in vivo neuroendocrine model in female sheep that allows full quantification of reproductive hormone secretion from the brain to the gonad, the ability to map the specific neuronal populations and pathways that control neuroendocrine function, and to quantify sexual behaviour.

To this end, we developed models and novel techniques that enabled complete dissection of each locus with potential to mediate the effect of cortisol on reproduction. These include the hypophyseal portal sampling technique, the pituitary clamp model, the artificial follicular phase model and the layered stress paradigm. The portal sampling technique is one critical aspect of our approach. This unique ability allows collection of multiple samples from the pituitary portal blood system in unanaesthesized animals to quantify the dynamics of the secretion of GNRH. This is the only approach that can be used to quantify the effects of cortisol on the output of the brain essential for reproduction (i.e., the GNRH secretory profile), as we have done (Oakley et al. 2009a,b). Together with the other approaches, it thereby provides a complete picture of the effects of cortisol on every aspect of the hypothalamic-pituitary unit governing reproduction. In the pituitary clamp model, endogenous GNRH and LH secretion is inhibited by the strong negative feedback effects of oestradiol during the non-breeding season and then the secretion of $\mathrm{LH}$ is re-established by injecting a fixed dose of GNRH at regular intervals. This model allows direct actions at the anterior pituitary to be examined. Disruption of the fixed pattern of secretion of $\mathrm{LH}$ in response to the injections of GNRH indicates actions that affect the responsiveness of the anterior pituitary to the actions of GNRH. In the artificial follicular phase model, the secretory patterns of reproductive hormones of the oestrous cycle are established in ovariectomized ewes through the systematic treatment with progesterone and 
oestradiol (Breen \& Karsch 2004). GNRH and LH surges are induced, as well as sexual receptivity (oestrus) (Goodman et al. 1981, Moenter et al. 1990, Evans et al. 1996, 1997, Wagenmaker et al. 2009, Papargiris et al. 2011a).

\section{Role of cortisol in influencing the impact of stress on tonic secretion of GNRH and LH}

Using these techniques, we tested whether cortisol, either given exogenously or elevated by psychosocial stress, was sufficient and/or necessary to suppress tonic GNRH secretion and tonic $\mathrm{LH}$ secretion in the presence and in the absence of gonadal steroids. In the first of these experiments, it was imperative to demonstrate that cortisol, in the absence of gonadal steroids, was sufficient to inhibit pulsatile secretion of LH. Cortisol was administered to ovariectomized ewes at two levels that evoked stress-like circulating cortisol concentrations of $\sim 75$ or $\sim 150 \mathrm{ng} / \mathrm{mL}$ (Breen \& Karsch 2006b). Both doses of cortisol rapidly suppressed pulsatile LH release in a dose-dependent manner. At $\sim 75 \mathrm{ng} / \mathrm{mL}$ cortisol, mean plasma $\mathrm{LH}$ was decreased by $28 \%$ due to a $42 \%$ decrease in pulse amplitude and at $\sim 150 \mathrm{ng} / \mathrm{mL}$ LH was suppressed by $45 \%$, reflecting a $56 \%$ decrease in pulse amplitude. These effects were rapid and occurred within $1-2 \mathrm{~h}$ of cortisol administration. These findings in conjunction with a follow-up study showed that stresslike concentrations of cortisol were sufficient to suppress LH pulse amplitude (Breen \& Karsch 2006a).

With the sufficiency of cortisol to suppress LH secretion established the next step was to determine the neuroendocrine loci responsible for this suppression. Pituitary portal blood and peripheral blood were collected from ovariectomized ewes at 10-min intervals for $6 \mathrm{~h}$ before and $6 \mathrm{~h}$ during constant infusion of either cortisol or a vehicle (Breen \& Karsch 2006a). The cortisol infusion rate resulted in a plasma cortisol concentration of $\sim 150 \mathrm{ng} / \mathrm{mL}$. These studies showed that although cortisol suppressed pulsatile LH secretion, it had no effect of GNRH secretion. These findings established the hypothesis that cortisol acts to suppress LH secretion by reducing the sensitivity of the anterior pituitary gland to GNRH rather than by reducing GNRH secretion. This hypothesis was confirmed in a second study, using the pituitary clamp model, where endogenous GNRH pulses were blockaded with oestradiol and GNRH was administered by hourly GNRH injections (Breen \& Karsch 2006a). Once again, cortisol administration suppressed LH secretion whereas vehicle did not, confirming that a reduction in pituitary sensitivity to $\mathrm{GNRH}$ mediates the effect of cortisol on $\mathrm{LH}$ secretion in ovariectomized ewes.

We had now demonstrated that cortisol is sufficient to suppress $\mathrm{LH}$ secretion in ovariectomized ewes, and that in the absence of gonadal steroids, cortisol acts by reducing the sensitivity of the pituitary to $\mathrm{GNRH}$. Nevertheless, it was not known which of the glucocorticoid receptors were implicated in this effect. In another series of experiments, it was established that the effects of cortisol on $\mathrm{LH}$ secretion could be attenuated by blockade of the type II glucocorticoid receptor with RU486 (Breen \& Karsch 2004, Breen et al. 2004b). In these experiments, pituitary portal blood and peripheral blood were collected every $10 \mathrm{~min}$ for $13 \mathrm{~h}$; after $6 \mathrm{~h}$, ewes were administered the type I glucocorticoid receptor antagonist Spironolactone or a type II glucocorticoid antagonist RU486 or a vehicle. After $1 \mathrm{~h}$, cortisol infusion commenced and GNRH and $\mathrm{LH}$ pulses were measured for the final $6 \mathrm{~h}$. Only in the presence of RU486 were the effects of cortisol on $\mathrm{LH}$ secretion attenuated, thus confirming that the type II glucocorticoid receptor mediates the effect of cortisol on LH secretion in the absence of gonadal steroids. Collectively, these experiments demonstrated that cortisol is sufficient and necessary to suppress $\mathrm{LH}$ secretion in the absence of gonadal steroids and that this effect was mediated through type II glucocorticoid receptors in gonadotropes.

The effects of cortisol described above, mediated at a pituitary level by type II glucocorticoid receptors, were seen when cortisol was infused at a rate that mimics stress-like concentrations. The next set of experiments aimed to determine whether this was also the case when cortisol was elevated due to psychosocial stress. A layered stress paradigm was developed in which sequential hourly application of individual stressors such as social isolation, restraint, blindfolding and exposure to predatory cues results in a reliable elevation of plasma cortisol to $\sim 70-80 \mathrm{ng} / \mathrm{mL}$ (Breen et al. 2007). The layered stress paradigm was applied in ovariectomized ewes over a series of experiments. The first of these showed that when cortisol was elevated by psychosocial stress, it had the same effect on $\mathrm{LH}$ secretion as when it was infused (Breen et al. 2007) and that this effect was mediated at the anterior pituitary by reducing the sensitivity of the pituitary to GNRH (Breen et al. 2007). Further investigation using this model demonstrated that when RU486 was administered in concert with the layered stress paradigm, the effects of cortisol on pituitary sensitivity were attenuated. The studies by Breen and coworkers employed the pituitary clamp model, which was effective in determining that psychosocial stress affected the pituitary (Breen et al. 2007). It did not, however, provide information about the effect of psychosocial stress on GNRH secretion. Therefore, Wagenmaker and coworkers employed the layered stress paradigm and measured endogenous GNRH production and $\mathrm{LH}$ secretion during psychosocial stress in ovariectomized ewes (Wagenmarker et al. 2009). This approach showed that although RU486 attenuated the effects of cortisol on LH secretion at the level of the pituitary, it did not unambiguously 
attenuate the effects of cortisol on GNRH production during psychosocial stress (Wagenmaker et al. 2009). Although these experiments demonstrated that during psychosocial stress cortisol is sufficient and necessary to supress tonic secretion of $\mathrm{LH}$ in ovariectomized ewes at the pituitary level, but not at the hypothalamic level, the ewes were devoid of ovarian steroids. Combining these data suggested (1) that there may be other aspects of the stress response that can influence GNRH release in the brain during psychosocial stress or (2) that the ovarian steroids may be necessary for cortisol to affect GNRH secretion. Therefore, the next set of experiments aimed to determine the influence of the ovarian steroids on these interactions.

We demonstrated over a series of experiments using the artificial follicular phase model that only in the presence of oestradiol will cortisol suppress both $\mathrm{LH}$ and GNRH pulse amplitude and pulse frequency (Oakley et al. 2009a,b). In the absence of gonadal steroids, cortisol is only sufficient to suppress LH pulse amplitude. The first of these experiments employed two groups of 12 ewes. One group was ovariectomized and deprived of ovarian steroids for 8 months, whereas the other group was ovariectomized and immediately treated with oestradiol and progesterone implants. The oestradiol and progesterone implants were removed and re-implanted at regular intervals, such that hormonal concentrations mimicked the normal oestrous cycle (Oakley et al. 2009a,b). After 8 months, both groups of ewes were exposed to elevated cortisol for $29 \mathrm{~h}$. In the ewes implanted with oestradiol and progesterone, cortisol exposure began $1 \mathrm{~h}$ before progesterone withdrawal. In ewes devoid of gonadal steroids, $29 \mathrm{~h}$ of cortisol exposure suppressed LH amplitude but had no effect on LH pulse frequency. In the ewes that were maintained in the artificial oestrous cycle, $29 \mathrm{~h}$ of cortisol exposure decreased LH pulse amplitude and reduced LH pulse frequency. These experiments indicated that oestradiol is necessary for cortisol to suppress LH pulse frequency and indicated that the effect of cortisol on LH secretion varies with the reproductive state of the animal. These first experiments did not, however, indicate whether this effect was mediated at the pituitary by decreasing sensitivity to GNRH or at the hypothalamus by reducing GNRH pulse amplitude or frequency. This protocol was therefore repeated with the addition of portal sampling to measure GNRH pulse dynamics in concert with LH (Oakley et al. 2009a). This experiment showed that in ewes devoid of gonadal steroids, there was no effect of cortisol on GNRH. However, in ewes maintained in the artificial follicular phase, cortisol decreased GNRH pulse amplitude and reduced the GNRH pulse frequency as well as suppressed LH pulse amplitude and reduced LH pulse interval. This confirmed that gonadal steroids were necessary for cortisol to suppress $\mathrm{LH}$ pulse frequency and $\mathrm{LH}$ pulse amplitude. This combination of experiments demonstrated that in order for cortisol to reduce both LH pulse amplitude and LH pulse frequency, it must act at the pituitary to decrease sensitivity to GNRH and, at the same time, act at the hypothalamus to suppress GNRH pulse amplitude and reduce GNRH pulse frequency. The presence of the gonadal steroids is thus necessary for cortisol act at the hypothalamic level to suppress GNRH secretion.

In summary, cortisol can suppress tonic LH secretion by reducing the sensitivity of the pituitary to GNRH and by suppressing GNRH secretion from the hypothalamus. Cortisol in all cases is sufficient and necessary to suppress tonic $\mathrm{LH}$ secretion by reducing the sensitivity of the pituitary to GNRH and this manifests as a reduction in the amplitude of $\mathrm{LH}$ pulses. Antagonism of the type II glucocorticoid receptor does not entirely attenuate the suppressive effects of stress on GNRH secretion and this suggests that cortisol is sufficient but not unambiguously necessary for stress to suppress LH secretion by acting within the brain to suppress GNRH. The presence of gonadal steroids is necessary for cortisol to act at the level of the hypothalamus, but the exact mechanism responsible for this interaction remains elusive. Furthermore, under psychosocial stress, antagonism of the type II glucocorticoid receptor does not block the effect of cortisol on LH suppression, again indicating that there are factors other than cortisol that act in the brain, perhaps in the hypothalamus, to suppress $\mathrm{LH}$ secretion via the suppression of GNRH secretion. In all cases, cortisol is sufficient to suppress tonic LH secretion; however, there are stressful conditions in which cortisol may not be necessary to suppress LH secretion.

Although the exact mechanisms that mediate the effect of cortisol on GNRH secretion within the hypothalamus are yet to be determined, two likely neuronal populations have emerged as candidates. These are gonadotrophininhibiting hormone $(\mathrm{GnIH})$ neurons of the dorsomedial hypothalamus and KNDy neurons in the hypothalamic arcuate nucleus. GnlH was first identified for its suppressive effects on reproductive processes in avian species (Bentley et al. 2008, 2009, Tsutsui et al. 2009) and was proposed as a possible mediator of the effects of stress on reproduction (Bentley et al. 2008, 2009). Despite the mammalian homologue of $\mathrm{GnIH}$, RF-amiderelated peptide-3 (RFRP-3) being effective in suppressing GNRH and LH in sheep (for review Papargiris \& Tilbrook 2010), we showed that RFRP-3 is not a mediator of the inhibitory effects of psychosocial stress on LH secretion in ewes (Papargiris et al. 2011a). However, KNDy neurons have been shown to play a central role in the neuroendocrine control of reproduction (Goodman et al. 2007, Lehman et al. 2010a) and may well be the prime candidate to mediate the effect of cortisol on pulsatile LH secretion. This possibility is discussed in the "KNDy cells: mediators of the effects of cortisol on reproduction?" section. 


\section{Role of cortisol in influencing the impact of stress on surge secretion}

There is no doubt that other potential targets for stress to affect reproduction in females are the mechanisms driving the GNRH/LH surge that induces ovulation. A blocking or blunting of the preovulatory surge will result in abolition of ovulation or a delay in ovulation such that fertilization may not take place because spermatozoa are not deposited optimally relative to the presence of a secondary oocyte. Indeed, Moberg proposed that the likely effect of stress on female reproduction would depend on the stage of the reproductive cycle when the stress occurred (Moberg 1987). Although this hypothesis has not been rigorously tested in all species, it stands to reason that stress in the late follicular phase is more likely to interfere with the GNRH/LH surge and thereby affect ovulation than if this was to occur early in the follicular phase or in the luteal phase. There is certainly evidence that uncoupling neuroendocrine and ovarian events can affect reproduction. For example, delaying the LH surge in cattle by $11 \mathrm{~h}$ impaired early embryonic development (van de Leemput et al. 2001) and increased the length of oestrous cycle of the rat to 6 days, decreasing fertilization and implantation rates and increasing chromosomal abnormalities (Butcher et al. 1969, Butcher \& Fugo 1967). These findings highlight the importance of understanding the effects of stress on the preovulatory GNRH/LH surge.

There have been many studies in a range of species to show that various stressors interfere with the LH surge and these have been extensively reviewed (Dobson \& Smith 2000, Smith \& Dobson 2002, Tilbrook et al. 2002, Turner et al. 2002a, 2005, Breen \& Karsch 2006b, Dobson et al. 2012). These stressors include (1) transportation that delays or attenuates the LH surge in sheep and cows (Dobson 1987, Nanda et al. 1990, Dobson et al. 1999), (2) injection of insulin that delayed the LH surge in ewes (Saifullizam et al. 2010), (3) metabolic stress caused by caloric restriction that can disrupt and stop oestrous cycles in ewes (Wagenmaker et al. 2010), (4) restraint that can block the preovulatory surge in rats (Roozendaal et al. 1997a,b) and (5) immune/inflammatory stress that suppresses pulsatile LH secretion during the preovulatory period in sheep (Battaglia et al. 2000) and delays or blocks the LH surge in follicular phase ewes, cows and monkeys (Peter et al. 1989, Xiao et al. 1998, Battaglia et al. 2000). With respect to immune stress, endotoxin was shown to disrupt the oestradiol-induced LH surge in ovariectomized ewes by interfering with the early activating effects of the oestradiol signal (Battaglia et al. 1999) and by acting centrally to suppress the secretion of GNRH (Breen et al. 2004a). These actions do not require prostaglandins, which are necessary to suppress the GNRH pulses (Breen et al. 2004a), suggesting that some other mediator is involved. Despite the findings of these studies, we have also found that repeated exposure to various acute psychosocial stressors during a single follicular phase or over two oestrous cycles in the ewe did not alter the incidence, timing, amplitude or duration of the LH surge (Wagenmaker et al. 2010). This may suggest that the oestrous cycle of the ewe is remarkably resistant to acute bouts of psychosocial stress, similar to that of the female pig (Turner et al. 2002a). However, it may also highlight the importance of the severity of the stressor, given the other findings cited above. In keeping with the theme of this review, it is pertinent to consider that glucocorticoids may be involved in stress-induced inhibition of the preovulatory GNRH/LH surge.

The extent to which the impact of stress on surge secretion is due to cortisol is not well appreciated. The approaches used to address this have largely considered the LH surges following treatment with natural or synthetic glucocorticoids. The results of these treatments indicate that glucocorticoids are sufficient to interfere with the LH surge but they do not address the issue of necessity and this remains an area requiring research. In pigs, a sustained elevation of cortisol inhibited the LH surge, oestrus and ovulation (Turner et al. 1999), and in rats, the synthetic glucocorticoid dexamethasone blocked the LH surge (Baldwin \& Sawyer 1974, Baldwin 1979). Furthermore, cortisol was implicated as having disruptive effects on preovulatory events in ewes that were infused with this steroid during the early-to-midfollicular phase (Breen et al. 2005). The levels of cortisol achieved were one third, half or the maximal value induced by isolation, and the effects were to attenuate the high-frequency LH pulses typical of the preovulatory period, prevent or delay the follicular phase oestradiol rise, and delay or block the $\mathrm{LH}$ and FSH surges (Breen et al. 2005).

These findings led us to conduct two further studies to explore the actions of cortisol to inhibit the LH surge in ewes, and both studies demonstrated that cortisol can interfere with the positive feedback effects of oestradiol to generate an LH surge (Wagenmaker et al. 2009). Both studies used an artificial follicular phase model (Goodman et al. 1981, Clarke et al. 1989, Moenter et al. 1990, Breen et al. 2004a) in which ovariectomized ewes were treated with progesterone and oestradiol to induce artificial oestrous cycles. Cortisol was infused i.v. resulting in plasma concentrations twice (Pierce et al. 2009a) or 1.5 (Wagenmaker et al. 2009) times the concentrations achieved from treatment with endotoxin and both treatments resulted in a delay of the LH surge and a reduced amplitude of the surge. In one of these studies, we showed that these effects occurred in both the breeding and non-breeding season with the delay in the LH surge being more pronounced in the nonbreeding season (Pierce et al. 2009a). Furthermore, in this study, cortisol reduced the incidence of the $\mathrm{LH}$ surge, with surges being absent in 7/18 ewes (Pierce et al. 2009a). In contrast, in our other study, we found no effect of cortisol on the incidence of the LH surge 
(Wagenmaker et al. 2009). The reasons for the divergent findings are not clear but may be due to the differences in the concentration of plasma cortisol achieved with the treatments in the respective studies and may suggest that cortisol will only block or prevent the LH surge in extreme cases. Indeed, the pattern and extent of elevated circulating cortisol seems important because repeated acute elevations of cortisol in the blood did not affect the LH surge in gilts, whereas a sustained elevation of cortisol did (Turner et al. 1999). Nevertheless, it is clear that chronic elevations of cortisol interfere with the positive feedback actions of oestradiol to induce the GNRH/LH surges.

The mechanisms for these inhibitory effects of cortisol on the surge are not clear but are likely to be multiple in number. The delay in the LH surge caused by cortisol probably reflects an action on GNRH secretion because oestradiol induces a large surge of GNRH in the artificial follicular phase model (Moenter et al. 1990) and this is essential to initiate an LH surge. The actions of cortisol to inhibit GNRH are likely to be indirect because GNRH neurons in the ewe do not contain type II glucocorticoid receptors (Dufourny \& Skinner 2002a). This clearly suggests that other interneuronal pathways are involved but these have hitherto not been identified. Reductions in the amplitude of the $\mathrm{LH}$ surge by cortisol (Wagenmaker et al. 2009, Pierce et al. 2009a) suggest that cortisol may also act on the anterior pituitary to inhibit response to GNRH in the ewe (Breen \& Karsch 2004, Breen et al. 2008, Pierce et al. 2009b). This supports findings in rats where glucocorticoids were found to disrupt the oestradiol-induced LH surge in response to exogenous GNRH (Baldwin 1979) and transport stress has been shown to have a similar effect in ewes (Phogat et al. 1999). Nevertheless, reductions in the amplitude of the LH surge may be due to reductions in the GNRH stimulus, which means that there is a need to delineate hypothalamic and pituitary effects of cortisol. Clearly, the mechanisms by which cortisol acts within the hypothalamus and anterior pituitary to suppress the secretion and actions of GNRH to induce gonadotrophin surges requires substantial investigation.

Although it is apparent that cortisol has the capability of suppressing the GNRH/LH surge, its physiological relevance remains to be determined. As our studies with sheep (Wagenmaker et al. 2009) used a cortisol infusion that was based on a treatment with endotoxin that disrupted the LH surge in the artificial follicular phase model (Battaglia et al. 1999), it is likely that cortisol contributes to disruption of the positive feedback effects of oestradiol in response to this severe immune/inflammatory stress. This possibility is supported by the finding that the detrimental effects of endotoxin on the oestradiolinduced LH surge are not mediated by prostaglandins, which, as mentioned above, are mediators of the effects of immune/inflammatory stress on the pulsatile secretion of GNRH and LH (Rivest \& Rivier 1993, Harris et al. 2000). Nevertheless, caution needs to be exercised in extending this interpretation to other less severe stressors, such as transport, that induce smaller and briefer elevations in cortisol concentrations. Fundamentally, there is a need for research to firmly establish the extent to which cortisol is an essential mediator of the stress-induced disruption of the GNRH/LH surge. Furthermore, the biological relevance of inhibitory effects of cortisol on the surge needs to be determined. Possibilities may include an adaptive value of reducing the prospect of pregnancy in animals with infectious or immune/inflammatory disease or with adrenal disorders in humans that have chronically elevated cortisol (e.g. Cushing's disease), thereby allowing portioning of metabolic energy in a manner that optimizes survival. These hypotheses have yet to be tested.

\section{Role of cortisol in influencing the impact of stress on sexual behaviour}

Research on the impact of stress on sexual behaviour has received far less attention than the impact of stress on other aspects of reproduction, especially those involving endocrine and neuroendocrine events. A corollary of this is that the mechanisms and mediators of the actions of stress on sexual behaviour, and the involvement of cortisol particularly, are not well understood. This is not only because there has been less research on stress and sexual behaviour but also because the research has been less detailed. For example, with sheep, most studies on the effects of stress and cortisol on behaviour have focussed only on the incidence or timing of oestrus, which is the phase of the reproductive cycle in which ewes are sexually receptive to rams and will display the sexual behaviour that is necessary for copulation. Generally, the detailed components of sexual behaviour have not been considered. Thus, thermal stress was found to reduce sexual behaviour (Maurya et al. 2005) and disrupt the timing of oestrus (Doney et al. 1973) and transportation stress prevented oestrus (Ehnert \& Moberg 1991). In contrast, injection of ewes with insulin, which was used as an acute stressor, had no effect on the timing or frequency of various sexual behaviours (Saifullizam et al. 2010), possibly highlighting the importance of different types of stressors. Moreover, treatment with dexamethasone or stress-like levels of cortisol delayed oestrus (Ehnert \& Moberg 1991, Macfarlane et al. 2000). Similar approaches have been used in other domestic and laboratory species. Nevertheless, we extended this research using sheep to investigate the detailed effects of stress and cortisol on the specific aspects of sexual behaviour that are essential for successful mating under natural conditions (Pierce et al. 2008). These features of sexual behaviour are attractivity, proceptivity (or 
proceptive behaviour) and receptivity (or receptive behaviour) that were defined by Beach (Beach 1976, Papargiris et al. 2011b) and have been applied to many species, including sheep (Fabre-Nys 1983, Tilbrook et al. 1990, Fabre-Nys \& Martin 1991a,b, Fabre-Nys et al. 1993, Fabre-Nys \& Gelez 2007).

Attractivity is the stimulus value of the female in evoking sexual responses by the male. Proceptivity consists of appetitive activities by the female to initiate and maintain sexual interaction. Receptivity comprises behaviours by the female necessary and sufficient for copulation with a fertile male and is often referred to as the consummatory phase of sexual interaction (Beach 1976). The levels of attractivity (Pierce et al. 2008, Papargiris et al. 2011b), proceptivity and receptivity increase as the female approaches oestrus and they are maximal during oestrus (Tilbrook et al. 1990, Pierce et al. 2008, Papargiris et al. 2011b). Although these characteristics and their temporal changes apply to all healthy female livestock, there are individual differences between females in expression and levels of sexual behaviours that make this a challenging area to research. A clear example is individual differences in sexual "attractiveness" of ewes that influence their chances of being successfully mated (Tilbrook 1987a,b, Tilbrook \& Lindsay 1987, Tilbrook et al. 1987, Tilbrook \& Cameron 1989) and there are also likely to be differences among individuals in other aspects of sexual behaviour. There is an endocrine basis for the control of attractivity, proceptivity and receptivity with oestradiol playing an essential role in most species. In sheep, it is well understood that oestradiol is vital to stimulate oestrus following a period of progesterone priming (Robinson 1954, Blache et al. 1991). The importance of oestradiol has been clearly demonstrated in sheep in which the dose administered to ovariectomized ewes can influence the onset and duration of oestrus, with an increasing dose resulting in a quicker onset and longer duration (Lindsay 1966b, Scaramuzzi et al. 1971, Lindsay \& Fletcher 1972, Fabre-Nys \& Gelez 2007, Papargiris et al. 2011a). Although the actions of oestradiol to influence attractivity have not been investigated, it is clear that proceptivity and receptivity are regulated by the actions of oestradiol in the mediobasal hypothalamus/ ventromedial hypothalamic regions and the medial preoptic area (Herbison et al. 1993, Lehman et al. 1993, Blache et al. 1994, Scott et al. 2000, Tanaka et al. 2003).

We have examined the effects of psychosocial stress and cortisol on attractivity, proceptivity and receptivity in ewes using a well-characterized model in which ovariectomized ewes are artificially induced into oestrus (Pierce et al. 2008, Papargiris et al. 2011b). This model is composed of intramuscular injection of ovariectomized ewes with $20 \mathrm{mg}$ progesterone every $48 \mathrm{~h}$ for 12 days followed by an intramuscular injection of oestradiol benzoate $48 \mathrm{~h}$ after the final injection of progesterone (Tilbrook et al. 1990). If a dose of $25 \mu \mathrm{g}$ oestradiol benzoate is used, it will reliably induce oestrus in all ewes with an expected onset of oestrus 16-18 h after injection and an expected duration of oestrus of 24-26h (Tilbrook et al. 1990). As indicated above, both the onset and duration of oestrus can be altered by varying the dose of oestradiol benzoate. We conducted a series of experiments using this model in which the layered stress paradigm was imposed, or cortisol was infused to achieve stress-like plasma concentrations of cortisol, and measured sexual behaviour (Pierce et al. 2008). Stress reduced the attractivity and proceptivity of the ewes but had no effect on receptivity. In contrast, cortisol delayed the onset of oestrus and induced moderate avoidance behaviour in ewes, indicating reduced receptivity, but had no effect on attractivity and proceptivity (Pierce et al. 2008). Subsequently, the effects of cortisol were investigated in more detail revealing that both a long infusion (40h) and a short infusion ( $5 \mathrm{~h}$ ) of cortisol around the time of the injection of oestradiol benzoate inhibited receptivity but had no effect on attractivity or proceptivity of ewes. These results, together with dose studies, indicated that the effect of cortisol was to suppress the actions of oestradiol to induce receptivity (Pierce et al. 2008, Papargiris et al. 2011b). Hence, both psychosocial stress and cortisol suppress sexual behaviour in ewes but the specific effects and consequently the mechanisms of action differ. Stress suppresses the ability of ewes to attract rams (attractivity) and sexual motivation (proceptivity), whereas cortisol suppresses behaviour necessary for copulation (receptivity). Consequently, as psychosocial stress activates the HPA axis with a resultant increase in the synthesis of cortisol, it appears that cortisol is not the major mediator of the effects of psychosocial stress on sexual behaviour in ewes.

Despite these detailed studies, the mechanisms by which psychosocial stress inhibits sexual behaviour in females remain largely unknown and the mediators have not been conclusively identified, although a number of candidates exist. The task of identifying mechanisms for an impact of stress on attractivity is perplexing because little is known about the regulation of attractivity per se. It appears that stress impairs the release of stimuli from the female, which attract and evoke sexual responses in the male. These include both visual and olfactory cues (Fletcher \& Lindsay 1968, Beach 1976). Olfactory cues, in particular, play a key role. For example, rams prefer and are more sexually stimulated by ewes that have not been shorn, and it has been suggested that some components of the sexual "attractiveness" of the ewe, such as olfactory cues, are associated with her wool (Tilbrook 1987b, Tilbrook \& Cameron 1989). It is possible that stress reduces olfactory stimuli provided by ewes to rams, or interferes with the central processing of that information (Pierce et al. 2008, Pierce et al. 2009a, Papargiris et al. 2011b). Nevertheless, the mechanisms by which this might occur are unknown. A little more 
is known about the regulation of proceptivity, which provides more possibilities for mediators of the impact of stress on this component of sexual behaviour. Several neurotransmitters have been implicated in the regulation of proceptivity that may be affected by stress. In ewes, treatmentwithanantagonistofnorepinephrinesuppressed proceptivity with little effect on receptivity (Fabre-Nys et al. 1994); however, antagonism of norepinephrine in the mediobasal hypothalamus enhanced proceptive behaviour (Fabre-Nys et al. 2003). Norepinephrine has also been shown to increase transiently during sexual receptivity and following periods of sexual interactions with a male (Fabre-Nys et al. 1997). Interestingly, stress increases central norepinephrine concentrations in sheep (Turner et al. 2002b). Noradrenaline, but not neuropeptide $Y$, is elevated in cerebrospinal fluid from the third cerebral ventricle following audio-visual stress in gonadectomized rams and ewes (Turner et al. 2002b); however, the impact of this on sexual behaviour has not been investigated. There is evidence that serotonin and $\gamma$-aminobutyric acid inhibit oestrous behaviour in rodents and sheep (Ågmo et al. 1989, Mendelson 1992, Turner et al. 2002b, Fabre-Nys \& Gelez 2007); however, their possible roles as mediators of the effects of stress on sexual behaviour in other species have not been investigated. GNRH and oxytocin have been implicated as regulators of sexual behaviour in many species, including sheep (Fabre-Nys et al. 1997), but again their possible roles as mediators of the effects of stress are not known. An antagonist of GNRH reduced receptivity in ovariectomized ewes treated with progesterone and oestradiol (Caraty et al. 2002); however, it is unknown whether GNRH influences proceptivity or whether stress affects the actions of GNRH on the regulation of proceptivity and receptivity.

It is important to establish the mechanisms by which stress inhibits attractivity and receptivity because suppression of these components of sexual behaviour will jeopardize the chances of successful reproduction under natural conditions. Indeed, it is plausible that this effect of stress may be of greater importance than effects on the reproductive hormones for successful reproduction of sheep under natural conditions. This is because inhibition of attractivity and proceptivity could potentially mean that males and females never associate with copulate. Research on sheep has clearly shown that both parameters are important in determining the chances of a ewe being mated. For instance, the ability of ewes to attract rams under natural conditions affects their chances of being mated (Tilbrook et al. 1987), and the motivation of the ewe to seek the ram is vital to maximize the chances of successful mating. Ewes will make physical contact with rams (Banks 1964), seek out rams (Hafez 1951, 1952), mate with tethered rams (Inkster 1957a, Lindsay \& Robinson 1961, Lindsay \& Fletcher 1972, Allison \& Davis 1976), compete with other ewes for the attention of rams (Inkster 1957a,b,
Lindsay \& Robinson 1961, Lindsay 1966a, van der Westhuysen 1971, Tomkins \& Bryant 1972) and actually initiate a sexual episode during oestrus (Banks 1964, Tomkins \& Bryant 1972). Nonetheless, although it is clear that psychosocial stress reduces both the ability of ewes to attract rams and the motivation of ewes to solicit rams and to initiate and maintain sexual interactions, the actual impact of this on reproductive success needs to be quantified and the research needs to be extended to other species.

Although cortisol may not be a major mediator of the effects of psychosocial stress on sexual behaviour in females, the actions of cortisol to suppress receptivity also have important implications for the success of reproduction, at least in sheep. As indicated above, at least one important effect of cortisol is to inhibit the actions of oestradiol to stimulate receptivity (Papargiris et al. 2011b); however, the means by which cortisol achieves this have not been determined. Cortisol may act within the mediobasal hypothalamus/ ventromedial hypothalamic regions and the medial preoptic area where oestradiol acts because there are type II glucocorticoid receptors in these brain regions in the ewe (Dufourny \& Skinner 2002b). Interestingly, cortisol acts to inhibit the oestradiol signal to induce both receptivity (Papargiris et al. 2011b) and the LH surges (Wagenmaker et al. 2009, Pierce et al. 2009a), suggesting a commonality in the mechanisms. This may involve suppression of the secretion and/or actions of GNRH as it induces the LH surge (Moenter et al. 1990) and stimulates receptivity (Caraty et al. 2002). As discussed in section "KNDy cells: mediators of the effects of cortisol on reproduction?", such actions of cortisol would not be directly on GNRH neurons but would involve interneurons that provide afferent input to GNRH neurons, such as KNDy cells. This is unquestionably an area requiring research.

The divergent findings between the effects of psychosocial stress and cortisol on sexual behaviour, especially receptivity, pose the intriguing question of the physiological relevance of the actions of cortisol on sexual behaviour. Are the experimental findings relevant to every day challenges that animals might face? First, it must be recognized that the studies discussed above concerned only one category of stressor, psychosocial stress, which raises the possibility that cortisol may be an important mediator of the effects of other stressors. Different physiological conditions affect stress responses differently as well as the consequences of these stress responses (Tilbrook \& Clarke 2006). Secondly, as indicated in the introduction, in addition to stress-induced increases in glucocorticoids, there are clinical conditions in which the concentrations of glucocorticoids are pathologically high, and this is associated with reproductive dysfunction. Furthermore, the research above has been largely done with sheep and the relevance to other species is unknown. This 
underscores the need to fully appreciate how cortisol affects sexual behaviour in females.

\section{KNDy cells: mediators of the effects of cortisol on reproduction?}

It is apparent from the forgoing discussion that cortisol may inhibit reproductive processes through suppression of GNRH secretion and actions and that the type II glucocorticoid is involved, at least at the level of the anterior pituitary. Suppression of GNRH secretion will clearly result in inhibition of downstream endocrine events that are required for follicular development and ovulation. It is also likely that these actions will impair sexual receptivity. As indicated above, if the type II glucocorticoid receptors are involved in the central actions of cortisol to suppress GNRH secretion, the action must be via interneurons that contain the receptor and relay to $\mathrm{GNRH}$ neurons because GNRH neurons do not express the type II glucocorticoid receptors (Dufourny \& Skinner 2002a). One strong candidate is the population of KNDy neurons in the arcuate nucleus of the hypothalamus because they do contain type II glucocorticoid receptors, project to GNRH neurons and are involved in the regulation of GNRH secretion (Lehman et al. 2010a, Goodman \& Lehman 2012, Goodman et al. 2014).

As noted in the Introduction, KNDy cells are named for the three neuropeptides they express, kisspeptin (KISS), neurokinin B (NKB) and dynorphin (DYN), each of which has been implicated in the control of GNRH secretion in the ewe and other species (Goodman \& Lehman 2012). Kisspeptin is a powerful secretagogue for GNRH in many mammalian species including human, monkey, sheep, rat, mouse, hamster, goat and horse (Lehman et al. 2010b). The involvement of KISS in GNRH secretion was first recognized from studies of patients with hypogonadotrophic hypogonadism (De Roux et al. 2003, Seminara et al. 2003). These patients had a mutation in the KISS receptor (GPR54, now KISS1R) gene and were characterized by delayed or impaired onset of puberty, impaired gonadotrophin production and infertility. Similarly, the role of NKB was realized when individuals with a similar clinical presentation of hypogonadotrophic hypogonadism were shown to have a mutation in either the gene that encodes NKB or its receptor (NK3R) (Guran et al. 2009). These studies suggested that NKB and KISS had a stimulatory role in GNRH secretion and that each was critical for normal sexual development and the onset of puberty. Earlier work in sheep had indicated that the endogenous opioid peptide DYN mediates the negative feedback effect of progesterone on GNRH secretion (Goodman et al. 2004, Foradori et al. 2005). This hypothesis has since been extended to other species primarily through studies in which antagonism of the DYN receptor evokes inhibition of LH secretion (Navarro et al. 2009, Wakabayashi et al. 2010). Kisspeptin neurons are primarily located in the arcuate nucleus of the hypothalamus and the preoptic region, with smaller populations found in the amygdala and other regions. The KISS neurons found in the arcuate nucleus are unique in that they co-express DYN and NKB, and, unlike GNRH neurons, nearly all of them co-express gonadal steroid receptors, including those for progesterone, oestrogen and testosterone. KNDy cells have axons that directly synapse onto GNRH neurons or their processes (Lehman et al. 2013, Han et al. 2015) and by way of these contacts are thought to play a major role controlling GNRH secretion.

There is substantial evidence to support a key role for KNDy cells and their peptides in the feedback effects of oestradiol and progesterone on GNRH secretion (reviewed by Goodman et al. 2014). The dependence of the inhibitory effects of cortisol in the follicular phase on oestradiol, and its similarity to the inhibitory effects of progesterone during the luteal phase (Oakley et al. 2009b), suggests that the neural system responsible for the inhibitory influence of cortisol overlaps at a cellular level with that of oestradiol and progesterone. KNDy cells are a likely site for the convergence of these signals, as the vast majority of them co-localizes oestrogen receptor (ER)-alpha, the isoform of ER responsible for negative feedback, as well as the progesterone receptor (Lehman et al. 2010a). In addition, pilot work using dual immunofluorescence suggests that KNDy cells (using DYN as a marker) in the middle ARC contain type II GR, thus indicating that they are potential targets for the direct action of cortisol, as well as oestradiol and progesterone.

As described above, exposure to psychosocial stress can result in a delayed and attenuated LH surge, anovulation, attenuated pulse amplitude and increased pulse frequency and suppression of sexual behaviour. Using a sheep model of neuroendocrine defects resulting from prenatal exposure to excess testosterone (Salloum et al. 2012), Cheng et al. (2010) showed that impaired E2-positive feedback, evidenced by delayed $\mathrm{LH}$ surge, and decreased progesterone-negative feedback, evidenced by increased pulse frequency, were correlated with a decrease in NKB and dynorphin, but not kisspeptin, in KNDy cells. In addition, exposure to prenatal testosterone resulted in decreased NK3R co-localization in KNDy cells (Ahn et al. 2015). These data support the hypothesis that deficits in tonic and surge secretion of $\mathrm{LH}$ are underpinned by altered KNDy cell function. As KNDy cells contain type II glucocorticoid receptors and are mediators of GNRH secretion under normal circumstances as well as in animal models of reproductive disease, it is tempting to speculate that KNDy cells also mediate the effects of stress on GNRH secretion.

Thus, one possibility is that the inhibitory effects of cortisol on GNRH secretion are due to alterations in the 
expression of KNDy peptides and their ultimate influence on the activity of GNRH neurons. In preliminary work, we have found that stress-like levels of cortisol, capable of reducing pulse frequency during the follicular phase, also significantly increase mRNA levels of one of the three KNDy peptides, DYN. Specifically, we found an increase in the number of preprodynorphin (PPD) mRNA-containing cells, and the mRNA content (silver grains) per cell, in the arcuate nucleus of cortisol-treated ewes compared with controls (M Lehman, unpublished observations). Interestingly, these changes were seen in KNDy cells of the middle but not caudal division of the arcuate nucleus, which correlates with preliminary data indicating regional differences in the co-localization of type II glucocorticoid receptor. We have seen similar increases in the number of DYN-immunoreactive neurons in the middle, but not caudal, arcuate nucleus of cortisol-treated ewes using the same model (A Oakley, L Coolan and M Lehman, unpublished observations). An increase in DYN mRNA and peptide within KNDy cells would lead to the inhibition of this population via its

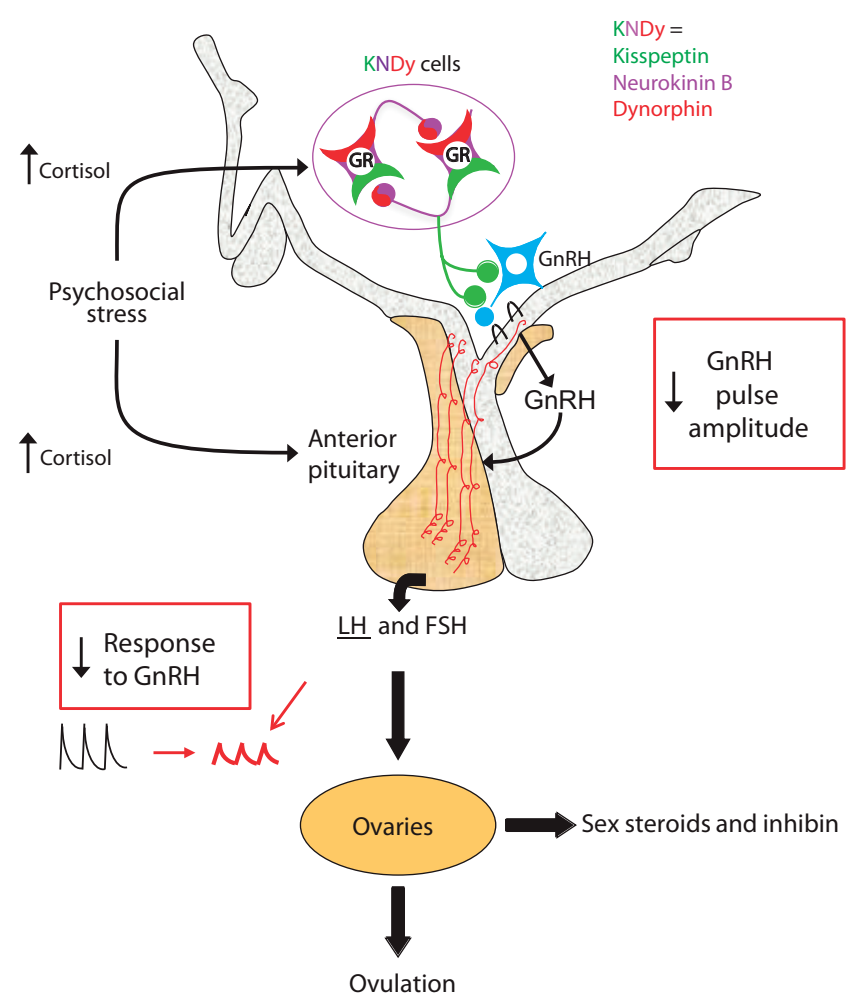

Figure 1 Suggested mechanisms of action of psychosocial stress on the pulsatile secretion of GNRH and LH in females. Psychosocial stress has suppressive actions at the hypothalamic and pituitary levels, which is mediated via cortisol in some reproductive states. We hypothesize that cortisol acts in the brain via type II glucocorticoid receptors (GR) located in the KNDy cells of the arcuate nucleus to increase dynorphin and/or decrease kisspeptin and neurokinin B. These changes lead to an increased inhibition of gonadotrophinreleasing hormone $(\mathrm{GNRH})$ neurons and their pulsatile secretion, as well as the GNRH surge, ultimately resulting in the inhibition of sexual behaviour (not shown in figure) and ovulation. reciprocal interconnections, and a decreased release of its stimulatory output (KISS) onto GNRH cells. It may be that cortisol also produces decreases in NKB and/or KISS contributing to an overall net inhibition of GNRH secretion. These possibilities need to be explored and, based on evidence of a cortisol-induced increase in DYN, research should also determine whether intracerebral delivery of a DYN (kappa opioid) antagonist is able to block the inhibitory effects of cortisol on GNRH pulses. In addition to establishing the role of KNDy neurons in mediating the effects of cortisol on reproduction at the level of the brain, it would also be worthwhile to determine whether the central actions of psychosocial stress on GNRH secretion involve the KNDy cells.

\section{Conclusion}

It is clear that cortisol is necessary for psychosocial stress to inhibit some, but not all, aspects of reproduction in female sheep. These actions vary with reproductive state, and there are important interactions between cortisol and gonadal steroids. The impact of the stressinduced actions of cortisol have been most extensively investigated with respect to the tonic secretion of GNRH and $\mathrm{LH}$, whereas effects on surge secretion and sexual behaviour have received less attention and less is known. Our research with sheep, using a combination of robust models that allow control of the reproductive cycle, delineation of sites of action within the reproductive axis and quantification of the effects of stress, have demonstrated when cortisol is sufficient to suppress the tonic secretion of reproductive hormones and when it is necessary to relay the effects of psychosocial stress. Although this represents a substantial advancement in our understanding of the mechanisms by which stress inhibits tonic secretion of GNRH and $\mathrm{LH}$ in females, whether cortisol is sufficient or necessary for stressinduced inhibition of surge secretion and/or sexual behaviour remains to be determined. These are areas requiring further rigorous research. Furthermore, research is required to establish the impact of psychosocial stress on reproduction in conditions when cortisol is not a mediator, or not a necessary mediator, of these effects.

During psychosocial stress, in the absence of gonadal steroids, cortisol is both sufficient and necessary to suppress tonic $\mathrm{LH}$ secretion through a reduction in the sensitivity of the anterior pituitary to GNRH, and this effect is mediated via type II glucocorticoid receptors. In contrast, cortisol does not have actions in the brain to suppress GNRH secretion in the absence of gonadal steroids. In the presence of gonadal steroids, however, cortisol suppresses GNRH secretion through actions in the hypothalamus (in addition to its effects at the pituitary; Fig. 1). These interactions between gonadal steroids and cortisol will likely have important roles in influencing the impact of stress on the secretion of $\mathrm{GNRH}$ and $\mathrm{LH}$ in different reproductive states. 
Although it is clear that stress can negatively affect the surge secretion of GNRH and the gonadotrophins, the extent to which this is due to cortisol remains to be fully elucidated. Nevertheless, both stress and chronic elevations of cortisol interfere with the positive feedback actions of oestradiol to induce the GNRH/ gonadotrophin surges. Experimental findings have consistently shown that cortisol can delay the LH surge and reduce the amplitude of the surge; however, there are inconsistencies in the extent to which cortisol inhibits the incidence of the LH surge and in the effect of season on these actions. Furthermore, acute psychosocial stress does not always alter the incidence, timing, amplitude or duration of the LH surge. Therefore, in addition to the need to establish the extent to which cortisol relays the effects of stress on surge secretion, there is also a requirement to understand the importance of the type and severity of stressor.

Psychosocial stress clearly inhibits sexual behaviour in female sheep, but cortisol does not appear to be its significant mediator. Stress suppresses attractivity and proceptivity, but cortisol has no effect on these aspects of sexual behaviour. Exogenous cortisol suppresses receptivity but the biological significance of this is not known. As stress activates the HPA axis and increases the secretion of cortisol, an effect of cortisol on attractivity and proceptivity would be expected if it was a principal mediator of the effects of stress on sexual behaviour. The mediators of stress on sexual behaviour have not been determined. However, there is evidence to suggest that there may be value in exploring the roles of various neurotransmitters including norepinephrine, serotonin and $\gamma$-aminobutyric acid. Furthermore, the role of GNRH in the regulation of receptivity and the impact of stress on this should be examined.

The central actions of cortisol during stress to inhibit GNRH secretion in female sheep, whether during tonic or surge secretion, must be indirect, involving neuronal populations that provide input to GNRH neurons because there are no type II glucocorticoid receptors on GNRH neurons. KNDy cells are likely candidates for this population, but this hypothesis remains to be rigorously tested (Fig. 1). Finally, as there are stressful conditions in which cortisol may not be necessary to inhibit reproduction in females, other factors that mediate the effects of stress on reproduction in females are yet to be identified.

The advancement in knowledge articulated in this review has important implications for the fields of reproductive biology and stress. There is an opportunity to translate these findings to the management of reproductive fitness in humans, domestic and endangered species, as well as animal welfare. With respect to humans, the sheep may well be a better model for stressed-induced infertility than rodents because the neuroendocrine control of reproduction in sheep more closely parallels this control in humans. We now have a platform upon which to launch research to overcome the impact of excessive cortisol synthesis on the aspects of female human reproduction such as menstrual cycles, ovulation, fertility and psychosexual function.

\section{Declaration of interest}

The authors declare that there is no conflict of interest that could be perceived as prejudicing the impartiality of the research reported.

\section{Funding}

This research did not receive any specific grant from any funding agency in the public, commercial or not-for-profit sector.

\section{References}

Ågmo A, Soria P \& Paredes R 1989 GABAergic drugs and lordosis behavior in the female rat. Hormones and Behavior 23 368-380. (doi:10.1016/0018-506X(89)90050-0)

Ahn T, Fergani C, Coolen LM, Padmanabhan LM \& Lehman MN 2015 Prenatal testosterone excess decreases neurokinin 3 receptor immunoreactivity within the arcuate nucleus kndy cell population. Journal of Neuroendocrinology 27 100-110. (doi:10.1111/jne.2015.27. issue-2)

Allison AJ \& Davis GH 1976 II. Effects of age of ewe, live weight, and paddock size on duration of oestrus and ram-seeking activity. New Zealand Journal of Experimental Agriculture 4 269-274. (doi:10.1080/ 03015521.1976.10425882)

Baldwin DM 1979 The effect of glucocorticoids on estrogen-dependent luteinizing hormone release in the ovariectomized rat and on gonadotropin secretin in the intact female rat. Endocrinology $\mathbf{1 0 5}$ 120-128. (doi:10.1210/endo-105-1-120)

Baldwin DM \& Sawyer CH 1974 Effects of dexamethasone on LH release and ovulation in the cyclic rat. Endocrinology 94 1397-1403. (doi:10.1210/endo-94-5-1397)

Banks EM 1964 Some aspects of sexual behavior in domestic sheep, Ovis aries. Behaviour 23 249-278. (doi:10.1163/156853964X00175)

Battaglia DF, Beaver AB, Harris TG, Tanhehco E, Viguie C \& Karsch FJ 1999 Endotoxin disrupts the estradiol-induced luteinizing hormone surge: interference with estradiol signal reading, not surge release. Endocrinology 140 2471-2479.

Battaglia DF, Krasa HB, Padmanabhan V, Viguie C \& Karsch FJ 2000 Endocrine alterations that underlie endotoxin-induced disruption of the follicular phase in ewes. Biology of Reproduction 62 45-53. (doi:10.1095/biolreprod62.1.45)

Beach FA 1976 Sexual attractivity, proceptivity, and receptivity in female mammals. Hormones and Behavior 7 105-138. (doi:10.1016/0018506X(76)90008-8)

Bentley GE, Ubuka T, McGuire NL, Chowdhury VS, Morita Y, Yano T, Hasunuma I, Binns M, Wingfield JC \& Tsutsui K 2008 Gonadotropininhibitory hormone and its receptor in the avian reproductive system. General and Comparative Endocrinology 156 34-43. (doi:10.1016/j. ygcen.2007.10.003)

Bentley GE, Ubuka T, McGuire NL, Calisi R, Perfito N, Kriegsfeld LJ, Wingfield JC \& Tsutsui K 2009 Gonadotrophin-inhibitory hormone: a multifunctional neuropeptide. Journal of Neuroendocrinology $21276-$ 281. (doi:10.1111/jne.2009.21.issue-4)

Berga SL, Daniels TL \& Giles DE 1997 Women with functional hypothalamic amenorrhea but not journal forms of anovulation display amplified cortisol concentrations. Fertility and Sterility 67 1024-1030. (doi:10.1016/S0015-0282(97)81434-3)

Bertagna X, Guignat L, Groussin L \& Bertherat J 2009 Cushing's disease. Best Practice \& Research Clinical Endocrinology \& Metabolism 23 607-623. 
Blache D, Fabre-Nys CJ \& Venier G 1991 Ventromedial hypothalamus as a target for oestradiol action on proceptivity, receptivity and luteinizing hormone surge of the ewe. Brain Research 546 241-249. (doi:10.1016/0006-8993(91)91488-M)

Blache D, Batailler M \& Fabre-Nys C 1994 Oestrogen receptors in the preoptico-hypothalamic continuum: immunohistochemical study of the distribution and cell density during induced oestrous cycle in ovariectomized ewe. Journal of Neuroendocrinology 6 329-339. (doi:10.1111/jne.1994.6.issue-3)

Breen KM \& Karsch FJ 2004 Does cortisol inhibit pulsatile luteinizing hormone secretion at the hypothalamic or pituitary level? Endocrinology 145 692-698. (doi:10.1210/en.2003-1114)

Breen KM \& Karsch FJ 2006a Does season alter responsiveness of the reproductive neuroendocrine axis to the suppressive actions of cortisol in ovariectomized ewes? Biology of Reproduction 74 41-45.

Breen KM \& Karsch FJ 2006b New insights regarding glucocorticoids, stress and gonadotropin suppression. Frontiers in Neuroendocrinology 27 233-245.

Breen KM, Billings HJ, Debus N \& Karsch FJ 2004a Endotoxin inhibits the surge secretion of gonadotropin-releasing hormone via a prostaglandinindependent pathway. Endocrinology 145 221-227.

Breen KM, Stackpole CA, Clarke IJ, Pytiak AV, Tilbrook AJ, Wagenmaker ER, Young EA \& Karsch FJ 2004b Does the type II glucocorticoid receptor mediate cortisol-induced suppression in pituitary responsiveness to gonadotropin-releasing hormone? Endocrinology 145 2739-2746.

Breen KM, Billings HJ, Wagenmaker ER, Wessinger EW \& Karsch FJ 2005 Endocrine basis for disruptive effects of cortisol on preovulatory events. Endocrinology 146 2107-2115. (doi:10.1210/en.2004-1457)

Breen KM, Davis TL, Doro LC, Nett TM, Oakley AE, Padmanabhan V, Rispoli LA, Wagenmaker ER \& Karsch FJ 2008 Insight into the neuroendocrine site and cellular mechanism by which cortisol suppresses pituitary responsiveness to gonadotropin-releasing hormone. Endocrinology 149 767-773. (doi:10.1210/en.2007-0773)

Butcher RL, Blue JD \& Fugo NW 1969 Overripeness and the mammalian ova. 3. Fetal development at midgestation and at term. Fertility and Sterility $20223-231$.

Butcher RL \& Fugo NW 1967 Overripeness and the mammalian ova. II. Delayed ovulation and chromosome anomalies. Fertility and Sterility $\mathbf{1 8}$ 297-302.

Caraty A Delaleu B, Chesneau D \& Fabre-Nys C 2002 Sequential role of E2 and $\mathrm{GnRH}$ for the expression of estrous behavior in ewes. Endocrinology 143 139-145. (doi:10.1210/endo.143.1.8605)

Clarke IJ, Cummins JT, Jenkin M \& Phillips DJ 1989 The oestrogen-induced surge of LH requires a 'signal' pattern of gonadotrophin-releasing hormone input to the pituitary gland in the ewe. Journal of Endocrinology 122 127-134. (doi:10.1677/joe.0.1220127)

De Roux N, Genin E, Carel JC, Matsuda F, Chaussain JL \& Milgrom E 2003 Hypogonadotropic hypogonadism due to loss of function of the KiSS1-derived peptide receptor GPR54. PNAS 100 10972-10976. (doi:10.1073/pnas.1834399100)

Dobson H 1987 Effect of transport stress on luteinizing hormone released by $\mathrm{GnRH}$ in dairy cows. Acta Endocrinologica 115 63-66.

Dobson H \& Smith RF 2000 What is stress, and how does it affect reproduction? Animal Reproduction Science 60-61 743-752. (doi:10.1016/S0378-4320(00)00080-4)

Doney JM, Gunn RG \& Griffiths JG 1973 The effect of premating stress on the onset of oestrus and on ovulation rate in Scottish blackface ewes. Journal of Reproduction and Fertility 35 381-384. (doi:10.1530/ jrf.0.0350381)

Dobson H, Tebble JE, Phogat JB \& Smith RF 1999 Effect of transport on pulsatile and surge secretion of $\mathrm{LH}$ in ewes in the breeding season. Journal of Reproduction and Fertility 116 1-8. (doi:10.1530/jrf.0.1160001)

Dobson H, Fergani C, Routly JE \& Smith RF 2012 Effects of stress on reproduction in ewes. Animal Reproduction Science 130 135-140. (doi:10.1016/j.anireprosci.2012.01.006)

Dufourny L \& Skinner DC 2002a Progesterone receptor, estrogen receptor $\alpha$, and the type II glucocorticoid receptor are coexpressed in the same neurons of the ovine preoptic area and arcuate nucleus: a triple immunolabeling study. Biology of Reproduction 67 1605-1612. (doi:10.1095/biolreprod.102.005066)

Dufourny L \& Skinner DC 2002b Type II glucocorticoid receptors in the ovine hypothalamus: distribution, influence of estrogen and absence of co-localization with GnRH. Brain Research 946 79-86.
Ehnert K \& Moberg GP 1991 Disruption of estrous behavior in ewes by dexamethasone or management-related stress. Journal of Animal Science 69 2988-2994.

Evans NP, Dahl GE, Caraty A, Padmanabhan V, Thrun LA \& Karsch FJ 1996 How much of the gonadotropin-releasing hormone (GnRH) surge is required for generation of the luteinizing hormone surge in the ewe? Duration of the endogenous GnRH signal. Endocrinology 137 4730-4737.

Evans NP, Dahl GE, Padmanabhan V, Thrun LA \& Karsch FJ 1997 Estradiol requirements for induction and maintenance of the gonadotropinreleasing hormone surge: implications for neuroendocrine processing of the estradiol signal. Endocrinology 138 5408-5414.

Fabre-Nys C 1983 Hormonal control of male and female sexual behaviour in ewes: Interactions between progesterone and oestradiol. Comptes Rendus des Seances de l'Academie des Sciences - Series III 296961 964.

Fabre-Nys C \& Gelez H 2007 Sexual behavior in ewes and journal domestic ruminants. Hormones and Behavior 52 18-25. (doi:10.1016/j. yhbeh.2007.04.001)

Fabre-Nys C \& Martin GB 1991a Hormonal control of proceptive and receptive sexual behavior and the preovulatory $\mathrm{LH}$ surge in the ewe: reassessment of the respective roles of estradiol, testosterone, and progesterone. Hormones and Behavior 25 295-312.

Fabre-Nys C \& Martin GB $1991 b$ Roles of progesterone and oestradiol in determining the temporal sequence and quantitative expression of sexual receptivity and the preovulatory LH surge in the ewe. Journal of Endocrinology $130367-379$.

Fabre-Nys C, Martin GB \& Venier G 1993 Analysis of the hormonal control of female sexual behavior and the preovulatory LH surge in the ewe: roles of quantity of estradiol and duration of its presence. Hormones and Behavior 27 108-121. (doi:10.1006/hbeh.1993.1008)

Fabre-Nys C, Blache D, Hinton MR, Goode JA \& Kendrick KM 1994 Microdialysis measurement of neurochemical changes in the mediobasal hypothalamus of ovariectomized ewes during oestrus. Brain Research 649 282-296. (doi:10.1016/0006-8993(94)91075-8)

Fabre-Nys C, Ohkura S \& Kendrick KM 1997 Male faces and odours evoke differential patterns of neurochemical release in the mediobasal hypothalamus of the ewe during oestrus: an insight into sexual motivation? European Journal of Neuroscience 9 1666-1677. (doi:10.1111/j.1460-9568.1997.tb01524.x)

Fletcher IC \& Lindsay DR 1968 Sensory involvement in the mating behaviour of domestic sheep. Animal Behaviour 16 410-414. (doi:10.1016/00033472(68)90032-8)

Foradori CD, Goodman RL, Adams VL, Valent M \& Lehman MN 2005 Progesterone increases dynorphin $\mathrm{A}$ concentrations in cerebrospinal fluid, and preprodynorphin messenger ribonucleic acid levels in a subset of dynorphin neurons in the sheep. Endocrinology 146 1835-1842. (doi:10.1210/en.2004-1326)

Goodman RL 2014 Neuroendocrine control of gonadotropin secretion: comparative aspects. In Knobil and Neill's Physiology of Reproduction: Two-Volume Set, pp 1537-1574. San Diego, CA, USA: Elsevier.

Goodman RL \& Lehman MN 2012 Kisspeptin neurons from mice to men: similarities and differences. Endocrinology 153 5105-5118. (doi:10.1210/en.2012-1550)

Goodman RL, Legan SJ, Ryan KD, Foster DL \& Karsch FJ 1981 Importance of variations in behavioural and feedback actions of oestradiol to the control of seasonal breeding in the ewe. Journal of Endocrinology 89 229-240. (doi:10.1677/joe.0.0890229)

Goodman RL, Coolen LM, Anderson GM, Hardy SL, Valent M, Connors JM, Fitzgerald ME \& Lehman MN 2004 Evidence that dynorphin plays a major role in mediating progesterone negative feedback on gonadotropinreleasing hormone neurons in sheep. Endocrinology 145 2959-2967. (doi:10.1210/en.2003-1305)

Goodman RL, Lehman MN, Smith JT, Coolen LM, De Oliveira CVR, Jafarzadehshirazi MR, Pereira A, Iqbal J, Caraty A, Ciofi P et al. 2007 Kisspeptin neurons in the arcuate nucleus of the ewe express both dynorphin A and neurokinin B. Endocrinology 148 5752-5760. (doi:10.1210/en.2007-0961)

Goodman RL, Coolen LM \& Lehman MN 2014 Unraveling the mechanism of action of the GnRH pulse generator. a possible role for Kisspeptin/Neurokinin B/Dynorphin (KNDy) neurons. In Cellular Endocrinology in Health and Disease, pp 133-152. London, UK: Academic Press. 
Guran T, Tolhurst G, Bereket A, Rocha N, Porter K, Turan S, Gribble FM, Kotan LD, Akcay T, Atay Z et al. 2009 Hypogonadotropic hypogonadism due to a novel missense mutation in the first extracellular loop of the neurokinin B receptor. Journal of Clinical Endocrinology and Metabolism 94 3633-3639. (doi:10.1210/jc.2009-0551)

Hafez ESE 1951 Mating behaviour in sheep. Nature 167 777-778. (doi:10.1038/167777a0)

Hafez ESE 1952 Studies on the breeding season and reproduction of the ewe Part III. The breeding season and artificial light Part IV. Studies on the reproduction of the ewe Part V. Mating behaviour and pregnancy diagnosis. Journal of Agricultural Science 42 232-265. (doi:10.1017/ S0021859600056902)

Han SY, McLennan T, Czieselsky K \& Herbison AE 2015 Selective optogenetic activation of arcuate kisspeptin neurons generates pulsatile luteinizing hormone secretion. PNAS 112 13109-13114. (doi:10.1073/ pnas.1512243112)

Harris TG, Battaglia DF, Brown ME, Brown MB, Carlson NE, Viguie C, Williams CY \& Karsch FJ 2000 Prostaglandins mediate the endotoxininduced suppression of pulsatile gonadotropin-releasing hormone and luteinizing hormone secretion in the ewe. Endocrinology 141 10501058.

Herbison AE, Robinson JE \& Skinner DC 1993 Distribution of estrogen receptor-immunoreactive cells in the preoptic area of the ewe: colocalization with glutamic acid decarboxylase but not luteinizing hormone-releasing hormone. Neuroendocrinology $\mathbf{5 7}$ 751-759. (doi:10.1159/000126433)

Inkster IJ 1957a The Breeding Behaviour of Two-Tooth Ewes. New Zealand Society of Animal Production, Hamilton, New Zealand.

Inkster IJ 1957b The mating behaviour of sheep. In Sheepfarming Annual, p 163. Palmerston North, New Zealand: Massey Agricultural College.

Lehman MN, Ebling FJP, Moenter SM \& Karsch FJ 1993 Distribution of estrogen receptor-immunoreactive cells in the sheep brain. Endocrinology 133 876-886.

Lehman MN, Coolen LM \& Goodman RL 2010a Minireview: Kisspeptin/ neurokinin B/dynorphin (KNDy) cells of the arcuate nucleus: a central node in the control of gonadotropin-releasing hormone secretion. Endocrinology 151 3479-3489.

Lehman MN, Merkley CM, Coolen LM \& Goodman RL 2010b Anatomy of the kisspeptin neural network in mammals. Brain Research 1364 90-102.

Lehman MN, Hileman SM \& Goodman RL 2013 Neuroanatomy of the kisspeptin signaling system in mammals: comparative and developmental aspects. Advances in Experimental Medicine and Biology 784 27-62. (doi:10.1007/978-1-4614-6199-9)

Lindsay DR 1966a Mating behaviour of ewes and its effect on mating efficiency. Animal Behaviour 14 419-424.

Lindsay DR $1966 b$ Modification of behavioural oestrus in the ewe by social and hormonal factors. Animal Behaviour14 73-83.

Lindsay DR \& Robinson TJ 1961 CEstrus-inducing activity of testosterone in the ewe. Nature 192 761-762. (doi:10.1038/192761a0)

Lindsay DR \& Fletcher IC 1972 Ram-seeking activity associated with oestrous behaviour in ewes. Animal Behaviour 20 452-456. (doi:10.1016/S0003-3472(72)80008-3)

Macfarlane MS, Breen KM, Sakurai H, Adams BM \& Adams TE 2000 Effect of duration of infusion of stress-like concentrations of cortisol on follicular development and the preovulatory surge of LH in sheep. Animal Reproduction Science 63 167-175. (doi:10.1016/S03784320(00)00179-2)

Maurya VP, Naqvi SMK, Gulyani R, Joshi A \& Mittal JP 2005 Effect of thermal stress on sexual behaviour of superovulated Bharat Merino ewes. Asian-Australasian Journal of Animal Sciences 18 1403-1406. (doi:10.5713/ajas.2005.1403)

Mendelson SD 1992 A review and reevaluation of the role of serotonin in the modulation of lordosis behavior in the female rat. Neuroscience and Biobehavioral Reviews 16 309-350. (doi:10.1016/S01497634(05)80204-0)

Moberg GP 1987 Influence of the adrenal axis upon the gonads. Oxford Reviews of Reproductive Biology 9 456-496.

Moenter SM, Caraty A \& Karsch FJ 1990 The estradiol-induced surge of gonadotropin-releasing hormone in the ewe. Endocrinology 127 13751384. (doi:10.1210/endo-127-3-1375)

Nanda AS, Dobson H \& Ward WR 1990 Relationship between an increase in plasma cortisol during transport-induced stress and failure of oestradiol to induce a luteinising hormone surge in dairy cows. Research in Veterinary Science 49 25-28.

Navarro VM, Gottsch ML, Chavkin C, Okamura H, Clifton DK \& Steiner RA 2009 Regulation of gonadotropin-releasing hormone secretion by kisspeptin/dynorphin/neurokinin B neurons in the arcuate nucleus of the mouse. Journal of Neuroscience 29 11859-11866. (doi:10.1523/ JNEUROSCI.1569-09.2009)

Oakley AE, Breen KM, Clarke IJ, Karsch FJ, Wagenmaker ER \& Tilbrook AJ 2009a Cortisol reduces gonadotropin-releasing hormone pulse frequency in follicular phase ewes: Influence of ovarian steroids. Endocrinology 150 341-349.

Oakley AE, Breen KM, Tilbrook AJ, Wagenmaker ER \& Karsch FJ $2009 b$ Role of estradiol in cortisol-induced reduction of luteinizing hormone pulse frequency. Endocrinology 150 2775-2782.

Papargiris MM \& Tilbrook AJ 2010 Effect of RF-related peptide-3 on luteinizing hormone and follicle stimulating hormone synthesis and secretion in ovine pituitary gonadotropes. Asia-Pacific Journal of Endocrinology 150 5549-5556.

Papargiris MM, Rivalland ETA, Clarke IJ, Smith JT, Pereira A \& Tilbrook AJ 2011a Evidence that RF-amide related peptide-3 is not a mediator of the inhibitory effects of psychosocial stress on gonadotrophin secretion in ovariectomised ewes. Journal of Neuroendocrinology 23 208-215.

Papargiris MM, Rivalland ETA, Hemsworth PH, Morrissey AD \& Tilbrook AJ 2011 b Acute and chronic stress-like levels of cortisol inhibit the oestradiol stimulus to induce sexual receptivity but have no effect on sexual attractivity or proceptivity in female sheep. Hormones and Behavior $60336-345$.

Peter AT, Bosu WT \& DeDecker RJ 1989 Suppression of preovulatory luteinizing hormone surges in heifers after intrauterine infusions of Escherichia coli endotoxin. American Journal of Veterinary Research $\mathbf{5 0}$ 368-373.

Phogat JB, Smith RF \& Dobson H 1999 Effect of transport on pituitary responsiveness to exogenous pulsatile $\mathrm{GnRH}$ and oestradiol-induced $\mathrm{LH}$ release in intact ewes. Journal of Reproduction and Fertility 116 9-18. (doi:10.1530/jrf.0.1160009)

Pierce BN, Hemsworth PH, Rivalland ETA, Wagenmaker ER, Morrissey AD, Papargiris MM, Clarke IJ, Karsch FJ, Turner AI \& Tilbrook AJ 2008 Psychosocial stress suppresses attractivity, proceptivity and pulsatile LH secretion in the ewe. Hormones and Behavior 54 424-434. (doi:10.1016/j.yhbeh.2008.04.005)

Pierce BN, Clarke IJ, Turner AI, Rivalland ETA \& Tilbrook AJ 2009a Cortisol disrupts the ability of estradiol- $17 \beta$ to induce the LH surge in ovariectomized ewes. Domestic Animal Endocrinology 36 202-208.

Pierce BN, Stackpole CA, Breen KM, Clarke IJ, Karsch FJ, Rivalland ET, Turner AI, Caddy DJ, Wagenmaker ER, Oakley AE et al. 2009b Estradiol enables cortisol to act directly upon the pituitary to suppress pituitary responsiveness to GnRH in sheep. Neuroendocrinology 89 86-97.

Rivest S \& Rivier C 1993 Centrally injected interleukin-1 beta inhibits the hypothalamic LHRH secretion and circulating LH levels via prostaglandins in rats. Journal of Neuroendocrinology 5 445-450. (doi:10.1111/jne.1993.5.issue-4)

Robinson TJ 1954 Relationship of oestrogen and progesterone in oestrous behaviour of the ewe. Nature 173 878. (doi:10.1038/173878a0)

Roozendaal MM, De Kruijf HF, Reuling RJ, Threels A, Swarts JJ, Wiegant VM \& Mattheij JA 1997a Inhibition of the LH surge by restraint stress in cyclic rats: studies on the role of GABAA and GABAB receptors. Stress 1 241-248.

Roozendaal MM, Swarts JJ, van Maanen JC, Wiegant VM \& Mattheij JA $1997 b$ Inhibition of the LH surge in cyclic rats by stress is not mediated by opioids. Life Sciences $\mathbf{6 0} 735-742$.

Saifullizam AK, Routly JE, Smith RF \& Dobson H 2010 Effect of insulin on the relationship of estrous behaviors to estradiol and LH surges in intact ewes. Physiology \& Behavior 99 555-561.

Salloum BA, Herkimer C, Lee JS, Veiga-Lopez A \& Padmanabhan V 2012 Developmental programming: prenatal and postnatal contribution of androgens and insulin in the reprogramming of estradiol positive feedback disruptions in prenatal testosterone-treated sheep. Endocrinology 153 2813-2822. (doi:10.1210/en.2011-2074)

Sapolsky RM, Romero ML \& Munck AU 2000 How do glucocorticoids influence stress responses? Integrating permissive, suppressive, stimulatory, and preparative actions. Endocrine Reviews 21 55-89.

Scaramuzzi RJ, Lindsay DR \& Shelton JN 1971 The effect of oestradiol benzoate on the duration of oestrous behaviour in the ovariectomized 
ewe. Journal of Endocrinology $50 \quad 345-346 . \quad$ (doi:10.1677/ joe.0.0500345)

Scott CJ, Pereira AM, Rawson JA, Simmons DM, Rossmanith WG, Ing NH \& Clarke IJ 2000 The distribution of progesterone receptor immunoreactivity and mRNA in the preoptic area and hypothalamus of the ewe: upregulation of progesterone receptor mRNA in the mediobasal hypothalamus by oestrogen. Journal of Neuroendocrinology 12 565-575.

Seminara SB, Messager S, Chatzidaki EE, Thresher RR, Acierno JS Jr, Shagoury JK, Bo-Abbas Y, Kuohung W, Schwinof KM, Hendrick AG et al. 2003 The GPR54 gene as a regulator of puberty. New England Journal of Medicine 349 1614-1627. (doi:10.1056/NEJMoa035322)

Smith RF \& Dobson H 2002 Hormonal interactions within the hypothalamus and pituitary with respect to stress and reproduction in sheep. Domestic Animal Endocrinology 23 75-85. (doi:10.1016/ S0739-7240(02)00147-9)

Spencer SJ \& Tilbrook A 2011 The glucocorticoid contribution to obesity. Stress 14 233-246. (doi:10.3109/10253890.2010.534831)

Tanaka T, Shiina T, Hayashi S, Okamura H, Kamomae H \& Kaneda Y 2003 Estrogen receptor alpha expression in the medial preoptic area and the medial basal hypothalamus under different physiological conditions in cattle. Journal of Reproduction and Development 49 55-60. (doi:10.1262/jrd.49.55)

Tilbrook AJ 1987a The influence of factors associated with oestrus on the sexual "attractiveness" of ewes to rams. Applied Animal Behaviour Science 17 117-128.

Tilbrook AJ 1987b Physical and behavioural factors affecting the sexual "attractiveness" of the ewe. Applied Animal Behaviour Science 17 109-115.

Tilbrook AJ \& Lindsay DR 1987 Differences in the sexual "attractiveness" of oestrous ewes to rams. Applied Animal Behaviour Science 17 129-138. (doi:10.1016/0168-1591(87)90015-3)

Tilbrook AJ \& Cameron AWN 1989 Ram mating preferences for woolly rather than recently shorn ewes. Applied Animal Behaviour Science $\mathbf{2 4}$ 301-312. (doi:10.1016/0168-1591(89)90058-0)

Tilbrook AJ \& Clarke IJ 2006 Neuroendocrine mechanisms of innate states of attenuated responsiveness of the hypothalamo-pituitary adrenal axis to stress. Frontiers in Neuroendocrinology 27 285-307. (doi:10.1016/j. yfrne.2006.06.002)

Tilbrook AJ, Cameron AWN \& Lindsay DR 1987 The influence of ram mating preferences and social interaction between rams on the proportion of ewes mated at field joining. Applied Animal Behaviour Science 18 173-184. (doi:10.1016/0168-1591(87)90191-2)

Tilbrook AJ, Hemsworth PH, Topp JS \& Cameron AWN 1990 Parallel changes in the proceptive and receptive behaviour of the ewe. Applied Animal Behaviour Science 27 73-92. (doi:10.1016/01681591(90)90008-2)

Tilbrook AJ, Turner Al \& Clarke IJ 2002 Stress and reproduction: central mechanisms and sex differences in non-rodent species. Stress 5 83-100. (doi:10.1080/10253890290027912)

Tomkins T \& Bryant MJ 1972 Mating behaviour in a small flock of lowland sheep. Animal Production 15 203-210.

Tsutsui K, Saigoh E, Yin H, Ubuka T, Chowdhury VS, Osugi T, Ukena K, Sharp PJ, Wingfield JC \& Bentley GE 2009 A new key neurohormone controlling reproduction, gonadotrophin-inhibitory hormone in birds: discovery, progress and prospects. Journal of Neuroendocrinology 21 271-275. (doi:10.1111/jne.2009.21.issue-4)

Turner AI, Hemsworth PH, Canny BJ \& Tilbrook AJ 1999 Sustained but not repeated acute elevation of cortisol impaired the LH surge, estrus and ovulation in gilts. Biology of Reproduction 61 614-620. (doi:10.1095/ biolreprod61.3.614)

Turner AI, Hemsworth PH \& Tilbrook AJ 2002a Susceptibility of reproduction in female pigs to impairment by stress and the role of the hypothalamo-pituitary-adrenal axis. Reproduction, Fertility and Development 14 377-391.

Turner AI, Rivalland ETA, Clarke IJ, Lambert GW, Morris MJ \& Tilbrook AJ $2002 b$ Noradrenaline, but not neuropeptide $Y$, is elevated in cerebrospinal fluid from the third cerebral ventricle following audiovisual stress in gonadectomised rams and ewes. Neuroendocrinology 76 373-380.

Turner AI, Hemsworth PH \& Tilbrook AJ 2005 Susceptibility of reproduction in female pigs to impairment by stress or elevation of cortisol. Domestic Animal Endocrinology 29 398-410. (doi:10.1016/j. domaniend.2005.02.031)

van de Leemput EE, Vos PL, Hyttel P, van den Hurk R, Bevers MM, van der Weijden GC \& Dieleman SJ 2001 Effects of brief postponement of the preovulatory LH surge on ovulation rates and embryo formation in eCG/prostaglandin-treated heifers. Theriogenology 55 573-592. (doi:10.1016/S0093-691X(01)00427-7)

van der Westhuysen JM 1971 Observations on the effects on season and age of the ewe on the mating behaviour of Merino rams. Agroanimalia 3 111-112.

Wagenmaker ER, Breen KM, Oakley AE, Pierce BN, Tilbrook AJ, Turner AI \& Karsch FJ 2009 Cortisol interferes with the estradiol-induced surge of luteinizing hormone in the ewe. Biology of Reproduction 80 458-463.

Wagenmaker ER, Breen KM, Oakley AE, Tilbrook AJ \& Karsch FJ 2010 The estrous cycle of the ewe is resistant to disruption by repeated, acute psychosocial stress. Biology of Reproduction 82 1206-1215. (doi:10.1095/biolreprod.109.078774)

Wakabayashi Y, Nakada T, Murata K, Ohkura S, Mogi K, Navarro VM, Clifton DK, Mori Y, Tsukamura H, Maeda KI et al. 2010 Neurokinin B and dynorphin $A$ in kisspeptin neurons of the arcuate nucleus participate in generation of periodic oscillation of neural activity driving pulsatile gonadotropin-releasing hormone secretion in the goat. Journal of Neuroscience 30 3124-3132. (doi:10.1523/JNEUROSCI.5848-09.2010)

Xiao E, Xia-Zhang L, Barth A, Zhu J \& Ferin M 1998 Stress and the menstrual cycle: relevance of cycle quality in the short- and long-term response to a 5-day endotoxin challenge during the follicular phase in the rhesus monkey. Journal of Clinical Endocrinology and Metabolism 83 2454-2460.

Received 21 December 2015

First decision 16 February 2016

Revised manuscript received 17 March 2016

Accepted 7 April 2016 